\title{
Karakteristik Membran Komposit Polietersulfon, Polivinilpirolidon dan Kitosan
}

\author{
Muhammad Fadli ${ }^{1}$, Al Khausar ${ }^{2}$, Sofyana $^{3}$, Ummi Fathanah ${ }^{4}$ \\ 1,2,3,4 Program Studi Teknik Kimia, Fakultas Teknik, Universitas Syiah Kuala, Banda Aceh \\ *Koresponden email: sofyana71@ unsyiah.ac.id
}

Diterima: 26 Agustus 2021

Disetujui: 8 Oktober 2021

\begin{abstract}
Polyethersulfone (PES) is a membrane forming material that has many advantages but is hydrophobic, so it is necessary to add other materials, such as composite PES with Polyvinylpyrrolidone (PVP) and chitosan. The addition of PVP aims to change the nature of the PES membrane to be hydrophilic and the addition of chitosan aims to improve the mechanical properties of the polymer. The purpose of this study was to study the effect of adding PVP and chitosan to the characteristics of PES membranes. The membranes were made using a phase inversion technique by immersion precipitation with a concentration of $20 \%$ PES, $1 \%$ PVP, and chitosan were varied, namely $0 \%$ (M0 membrane), $1.5 \%(\mathrm{M} 1), 2 \%(\mathrm{M} 2)$, and 3\% (M3). The results of the permeability test showed that the membranes M0, M1, M2, and M3 are classified as nanofiltration membranes with $\mathrm{Lp}$ values of $9.1237,7.618,6.9651$, and $4.4077 \mathrm{~L} / \mathrm{m}^{2}$. h.bar. The swelling degree value is 61,$512 ; 103.111 ; 145,564$; and $158.610 \%$ and the overall porosity value is $22.892 ; 32.360 ; 80.726$; and $117.016 \%$. The SEM test showed that the morphology of the membrane changed its structure as the concentration of chitosan increased. The FTIR test on the membrane showed that there were absorption bands, each of which identified its functional group.
\end{abstract}

Keywords: Membrane, Composite, Polyethersulfone (PES), Polyvinylpyrrolidone (PVP), Chitosan, Phase inversion

\begin{abstract}
Abstrak
Polietersulfon (PES) merupakan material pembentuk membran yang memiliki banyak kelebihan namun bersifat hidrofobik, sehingga perlu dilakukan penambahan bahan lainnya, seperti mengkompositkan PES dengan Polivinilpirolidon (PVP) serta kitosan. Penambahan PVP bertujuan untuk merubah sifat membran PES menjadi hidrofilik dan penambahan kitosan bertujuan untuk meningkatkan sifat mekanis polimer. Tujuan penelitian ini untuk mempelajari pengaruh penambahan PVP dan kitosan terhadap karakteristik membran PES. Membran dibuat dengan teknik inversi fasa secara presipitasi immerse dengan konsentrasi PES 20\%, PVP 1\%, dan kitosan divariasikan yaitu 0\% (Membran M0), 1,5\% (M1), 2\% (M2), dan 3\% (M3). Hasil uji permeabilitas menunjukkkan bahwa membran M0, M1, M2, dan M3 tergolong membran nanofiltrasi dengan nilai Lp sebesar 9,1237; 7,618; 6,9651; dan 4,4077 L/m².h.bar. Nilai swelling degree sebesar 61,$512 ; 103,111 ; 145,564$; dan $158,610 \%$ serta nilai overall porosity sebesar 22,892; 32,360; 80,726; dan 117,016\%. Uji SEM menunjukkkan bahwa morfologi membran mengalami perubahan struktur seiring bertambahnya konsentrasi kitosan. Uji FTIR pada membran menunjukkan terdapat pita serapan yang masing-masing mengidentifikasikan gugus fungsinya.
\end{abstract}

Kata Kunci: Membran, Komposit, Polietersulfon (PES), Polivinilpirolidon (PVP), Kitosan.

\section{Pendahuluan}

Kemajuan teknologi membran sebagai unit pengolahan limbah saat ini berkembang pesat dan sering dimanfaatkan dalam proses pemisahan. Operasi membran dapat diartikan sebagai proses mengisolasi dua atau lebih komponen dari fluida yang bergerak melalui membran. Membran berperan sebagai penghalang tipis yang sangat selektif diantara dua fasa, yaitu hanya dapat melewati komponen-komponen tertentu dan menahan komponen lainnya dari aliran fluida yang dilewatkan [1]. Pemisahan menggunakan teknologi membran mempunyai beberapa keunggulan dibandingkan dengan jenis-jenis pemisahan lainnya sehingga teknologi ini berkembang pesat. Kelebihan dari teknologi membran antara lain adalah pemisahan dapat berlangsung secara kontinyu, energi yang dibutuhkan rendah, dapat dikombinasikan dengan proses pemisahan lainnya, sifat dan variabel membran dapat disesuaikan, tidak membutuhkan zat additif yang banyak, hemat energi dan bersih, dapat dimanfaatkan untuk pemisahan fluida yang peka terhadap suhu (misalnya fluida biologis dan organik), dan tidak menghasilkan limbah [2]. Dengan keunggulan tersebut teknologi membran digunakan dalam aplikasi yang luas, misalnya penyaringan dan desinfeksi air minum, 
$\overline{\text { desalinasi air laut dan air payau, pemisahan gas, pemisahan dan pemekatan air limbah industri (waste water }}$ treatment), bioteknologi, dan pemisahan darah untuk penderita ginjal.

Keberhasilan pengaplikasian teknologi membran sangat dipengaruhi oleh material penyusun membran itu sendiri. Bahan utama pembuat membran umumnya terbuat dari bahan alami seperti polimer. Sebagian dari polimer yang sering digunakan sebagai bahan dasar untuk membuat membran diantaranya polyethersulfone (PES), polysulfone (PSF), polyethylene terephtalate (PET), cellulose acetate (CA), dan polyvinylidenfluoride (PVDF). PES (Polyethersulfone) merupakan polimer yang paling umum digunakan sebagai bahan pembentuk membran. Hal ini dikarenakan PES tahan terhadap suhu tinggi, ketahanan $\mathrm{pH}$ yang luas, memiliki kekuatan mekanik dan sintetik yang baik serta mudah untuk dibuat [3].

Dibalik kelebihannya, teknologi membran juga memiliki kekurangan, khususnya masalah fouling. Fouling ini dapat menyebabkan pengurangan kinerja membran dalam waktu yang relatif cepat. Mengubah struktur pori dan memperluas hidrofilisitas pada permukaan membran merupakan salah satu teknik yang dapat digunakan untuk mengurangi masalah fouling tersebut. Penambahan bahan organik dan anorganik ke dalam larutan dope telah dilaporkan sebagai spesialis pembentuk pori dan sebagai spesialis untuk mengubah struktur membran [4]. Dalam hubungan ini untuk meningkatkan stabilitas kimia, mekanik dan termal serta hidrofilisitas dan permeabilitas membran, membran matriks campuran sebagai salah satu jenis membran yang banyak digunakan, dibuat dengan memasukkan beberapa bahan tertentu dengan karakteristik yang signifikan ke dalam struktur membran seperti titania alumina, zinc oxide, silica, zirconia, besi oksida, polivinil alkohol, polietilen glikol dan polivinilpirolidon [5].

Saat ini teknologi membran dianggap sebagai teknologi terbaik yang dapat digunakan di berbagai negara untuk proses pemisahan. Nanofiltrasi adalah salah satu bidang yang berkembang pesat dan telah menjadi salah satu kemajuan besar akhir-akhir ini, terutama dalam pengolahan limbah di berbagai industri [6]. Membran Nanofiltrasi merupakan suatu pemisahan fase cair dimana jenis membran ini menggunakan daya dorong yang berada antara reverse osmosis (RO) dan ultrafiltrasi (UF). Dibandingkan dengan membran RO, membran nanofiltrasi mempunyai ukuran pori yang lebih fleksibel, dan memungkinkan dihasilkannya aliran yang lebih besar serta tekanan operasi yang lebih rendah. Sedangkan jika dibandingkan dengan membran UF struktur membran nanofiltrasi lebih rapat sehingga dapat menahan molekul organik kecil [7]. Nanoteknologi telah berkembang pesat dalam berbagai penelitian dan disiplin praktis. Salah satu contoh nanoteknologi ialah penggunaan nano partikel pada bahan pembentuk membran. Nano partikel menarik banyak perhatian dikarenakan dapat berfungsi sebagai agen yang menjanjikan dalam pembuatan membran matriks campuran. Memiliki dispersi yang lebih baik dalam matriks polimer (aksesibilitas yang lebih besar ke kelompok fungsional nanopartikel polimer) serta konsumsi yang lebih rendah menjadikan nanopartikel polimer sebagai alternatif yang efektif untuk polimer makro dalam pembuatan komposit [5]. Teknologi nanokomposit telah menarik banyak perhatian khususnya dibidang pembuatan membran dikarenakan dapat meningkatkan kemampuan kinerja membran.

Sejauh ini penambahan biopolimer ke dalam polimer pembentuk membran telah menarik banyak perhatian. Kitosan, sebagai biopolimer polisakarida dengan kandungan fungsi amina dan hidroksil yang signifikan, adalah turunan kitin yang memiliki banyak kegunaan dan dapat diterapkan. Kitosan memiliki beberapa kelebihan diantaranya hidrofilisitas tinggi, biokompatibilitas yang baik, non-toksisitas, biaya rendah, terbarukan, dan lain-lain. Terlepas dari kenyataan bahwa kitosan memiliki kemampuan meningkatkan sifat mekanis polimer, gugus amino dan hidroksilnya menghasilkan kemampuan menjadi adsorben untuk berbagai pewarna, makromolekul dan logam berat. Dengan demikian, adsorpsi fisik dan kimia dapat dipicu pada kitosan. Untuk tujuan ini, banyak studi penelitian telah dilakukan untuk menilai kemampuan adsorptif membran berbasis kitosan dalam menghilangkan kontaminan dari air seperti pewarna dan ion logam [5]. Membran nanokomposit kitosan telah dibuat dalam penelitian ini dimana kitosan telah dibuat dalam bentuk nanokitosan.

Jenis membran asimetris umumnya digunakan karena memiliki kekuatan mekanik yang lebih tinggi dari pada membran simetris. Teknik inversi fasa berdasarkan proses presipitasi imersi merupakan salah satu teknik yang paling banyak digunakan untuk membuat membran asimetrik [1]. Pada teknik ini membran yang baru dicetak kemudian direndam dalam bak koagulasi yang telah diisi larutan non pelarut. Larutan non pelarut adalah senyawa yang memiliki tingkat afinitas yang tinggi terhadap pelarut dan rendah terhadap polimer. Presipitasi imersi terjadi karena kelarutan yang rendah antara polimer dan non-larut. Bersamaan dengan itu, kelarutan yang tinggi antara pelarut dan non pelarut menyebabkan proses pergantian pelarut dengan non pelarut di beberapa titik sehingga mengakibatkan terjadi demixing. Pembentukan sublapisan pada membran asimetrik dipengaruhi oleh beberapa faktor yang terdapat pada larutan dope seperti komposisi, jenis aditif (organik atau anorganik) dan temperatur koagulasi [8]. Penelitian ini bertujuan untuk 
mengetahui karakteristik membran PES yang dibuat melalui teknik inversi fasa dengan menggunakan variable berupa variasi konsentrasi partikel nanokitosan.

\section{Metode Penelitian}

\section{Tempat dan Waktu Penelitian}

Penelitian ini telah dilaksanakan selama kurang lebih satu tahun yang dimulai pada bulan Juli 2019 hingga September 2020 di Laboratorium Polimer, Instrument dan Lingkungan Jurusan Teknik Kimia, Fakultas Teknik, Universitas Syiah Kuala.

\section{Alat dan Bahan}

Alat-alat yang digunakan antara lain gelas beaker, gelas vial, spatula, plat kaca, timbangan digital, labu ukur $250 \mathrm{~mL}$, gelas ukur $100 \mathrm{~mL}$, aluminium foil, aplikator (casting knife), modul membran, kertas saring whittman no. 41, oven, Fourier Transform InfraRed (FTIR), Scanning Electron Microscopy (SEM).

Bahan-bahan yang digunakan dalam penelitian ini antara lain polimer Polyethersulfone (PES), aditif Polyvinylpyrrolidone (PVP), pelarut Dimethyl Sulfoxide (DMSO), kitosan, dan aquades.

\section{Prosedur Penelitian}

\section{Proses Pembuatan Membran Asimetrik Secara Inversi Fasa}

Pembuatan membran dilakukan dengan menggunakan teknik inversi fasa secara presipitasi immerse, dengan non pelarut aquades. Pembuatan larutan cetak dilakukan dengan membuat suatu larutan homogeny campuran polimer PES ditambahkan PVP, partikel Kitosan dan pelarut DMSO. Diaduk selama 24 jam pada $400 \mathrm{rpm}$. Setelah 8 jam pengadukan, larutan disonikasi selama 15 menit untuk menghilangkan gelembung udara yang terbentuk selama pengadukan. Setelah pengadukan, membran dicetak diatas pencetak yang dibuat dari plat kaca. Pencetakan dilakukan menggunakan aplikator dengan ketebalan diatur setebal $150 \mu \mathrm{m}$. Setelah itu membran dicelupkan ke dalam bak koagulasi yang berisi larutan aquades sampai membran terlepas dari media pencetaknya yaitu plat kaca [5].

Formulasi larutan dope yang digunakan untuk membuat membran PES dengan variasi partikel nanokitosan sesuai variabel penelitian dapat dilihat pada Tabel 1 berikut.

Tabel 1. Formulasi dope untuk membuat membran

\begin{tabular}{ccccc}
\hline \multirow{2}{*}{ Nama Membran } & \multicolumn{4}{c}{ Formulasi dope (\% berat) } \\
\cline { 2 - 5 } & PES & Nanokitosan & PVP & DMSO \\
\hline M0 & 20 & 0 & 1 & 79 \\
M1 & 20 & 1,5 & 1 & 77,5 \\
M2 & 20 & 2 & 1 & 77 \\
M3 & 20 & 3 & 1 & 76 \\
\hline
\end{tabular}

Sumber : Data penelitian (2020)

\section{Permeabilitas Membran}

Nilai fluks (J) dan permeabilitas membran (Lp) dapat ditentukan dengan cara melewatkan air pada membran. Banyaknya volume permeat yang melalui membran persatuan luas persatuan waktu disebut sebagai fluks. Proses pengujian fluks membran dilakukan dengan modul nanofiltrasi sistem dead end. Untuk menguji fluks, membran dipotong terlebih dahulu menjadi berbentuk lingkaran sesuai dengan ukuran modul membran. Selanjutnya dimasukkan aquades dan ditutup rapat. Diberikan tekanan pada alat tersebut dengan variasi tekanan sebesar 3; 4; 5; 6 dan 7 bar dan diukur laju alir volumetriknya selama selang waktu 5 menit hingga volume konstan. Untuk menentukan fluks dan permeabilitas digunakan persamaan berikut [5]:

$$
\begin{aligned}
J & =\frac{V}{(A \times t)} \\
L p & =\frac{J}{\Delta P}
\end{aligned}
$$

Dimana:

$\mathrm{J} \quad=$ Fluks $\left(\mathrm{L} / \mathrm{m}^{2} . \mathrm{jam}\right)$

$\mathrm{V} \quad=$ Volume permeat $(\mathrm{L})$

$\mathrm{A} \quad=$ Luas permukaan $\left(\mathrm{m}^{2}\right)$

$\mathrm{t} \quad=$ Waktu (jam)

Lp $\quad=$ Permeabilitas

$\Delta \mathrm{P} \quad=$ Perbedaan tekanan (bar) 


\section{Swelling Degree dan Overall Porosity}

Swelling degree dilakukan untuk mengetahui seberapa banyak zat atau bahan yang dapat diserap oleh membran. Dalam penelitian ini, uji swelling dilakukan terhadap aquades. Membran direndam dengan aquades selama 24 jam pada suhu kamar, kemudian didiamkan hingga gelembung udara yang berasal dari membran keluar. Hal ini dimaksudkan agar air tertahan seluruhnya ke dalam membran untuk menggantikan udara yang terperangkap di dalam pori-pori membran. Sampel yang telah direndam diangkat dan disekat dengan kertas saring selama 1 jam, kemudian ditimbang beratnya dan dicatat sebagai berat basah. Selanjutnya membran dikeringkan menggunakan oven pada temperatur $50{ }^{\circ} \mathrm{C}$ selama 24 jam kemudian ditimbang beratnya dan dicatat sebagai berat kering. Data hasil pengukuran digunakan untuk menghitung nilai porositas dan derajat pengembangan membran atau swelling degree. Secara matematik porositas dan derajat pengembangan membran dapat diukur melalui persamaan berikut [5]:

$$
\begin{aligned}
\text { Porositas }(\%) & =\frac{(\text { berat basah }- \text { berat kering })}{(\rho \mathrm{H} 2 \mathrm{O} \times \text { volume benda })} \times 100 \\
\text { Derajat pengembangan }(\%) & =\frac{(\text { berat basah }- \text { berat kering })}{\text { (berat kering })} \times 100
\end{aligned}
$$

\section{Uji Morfologi Menggunakan SEM}

Analisa Scanning Electron Microscopy (SEM) merupakan alat yang digunakan untuk mengkarakterisasi morfologi dan mengetahui struktur pori sampel. Dengan menggunakan SEM, bentuk struktur pori pada penampang melintang membran dan pada dinding macrovoid dapat dilihat. Hasil analisa dengan SEM ini berupa fotopolaroid serta memiliki kemampuan untuk memfoto dengan perbesaran ukuran dari 35x hingga 10000x. Biasanya sampel yang difoto memiliki ukuran luas permukaan yang kecil yaitu 5 $\mathrm{mm} \times 5 \mathrm{~mm}$ dan sampel dalam kondisi kering. Apabila sampel yang ingin diuji bersifat tidak konduktif, maka sampel tersebut harus dilakukan pelapisan terlebih dahulu dengan menggunakan bahan yang konduktif.

\section{Uji Gugus Fungsi Menggunakan FTIR}

Instrumen yang digunakan untuk menguji gugus fungsi membran adalah FTIR spectroscopy. Uji FTIR dilakukan untuk menunjukkan bagaimana serapan gugus fungsi polimer pada sampel berdasarkan pada grafik yang ditampilkan pada layar komputer. Pengujian ini dilakukan pada semua varietas sampel sehingga diketahui gugus ikatan yang terkandung dalam tiap varietas sampel tersebut. Sebelum analisa gugus fungsi dilakukan, sampel membran terlebih dahulu dikeringkan dengan menggunakan vacuum freeze dryer. Kemudian IR spektrum dari membran PES direkam pada rentang bilangan gelombang 600-2000 $\mathrm{cm}^{-1}$.

\section{Hasil dan Pembahasan}

Membran PES+Nanokitosan yang telah dibuat diuji karakteristiknya berdasarkan beberapa variabel, diantaranya fluks dan koefisien permeabilitas membran (Lp), swelling degree dan overall porosity, stuktur morfologi membran menggunakan SEM, dan uji gugus fungsi membran menggunakan FTIR

\section{Fluks Air Murni dan Permeabilitas Membran}

Dengan memodifikasi komposisi pembuatan membran, telah dihasilkan empat buah membran yang memiliki struktur yang berbeda-beda. Untuk melihat perbedaan struktur membran tersebut telah dilakukan karakterisasi terhadap membran. Pengujian fluks dan permeabilitas merupakan salah satu karakterisasi membran yang telah dilakukan. Pengujian fluks dilakukan menggunakan umpan aquades untuk masingmasing jenis membran yang telah dibuat. Hasil uji fluks keempat jenis membran diperlihatkan pada Gambar 1. 


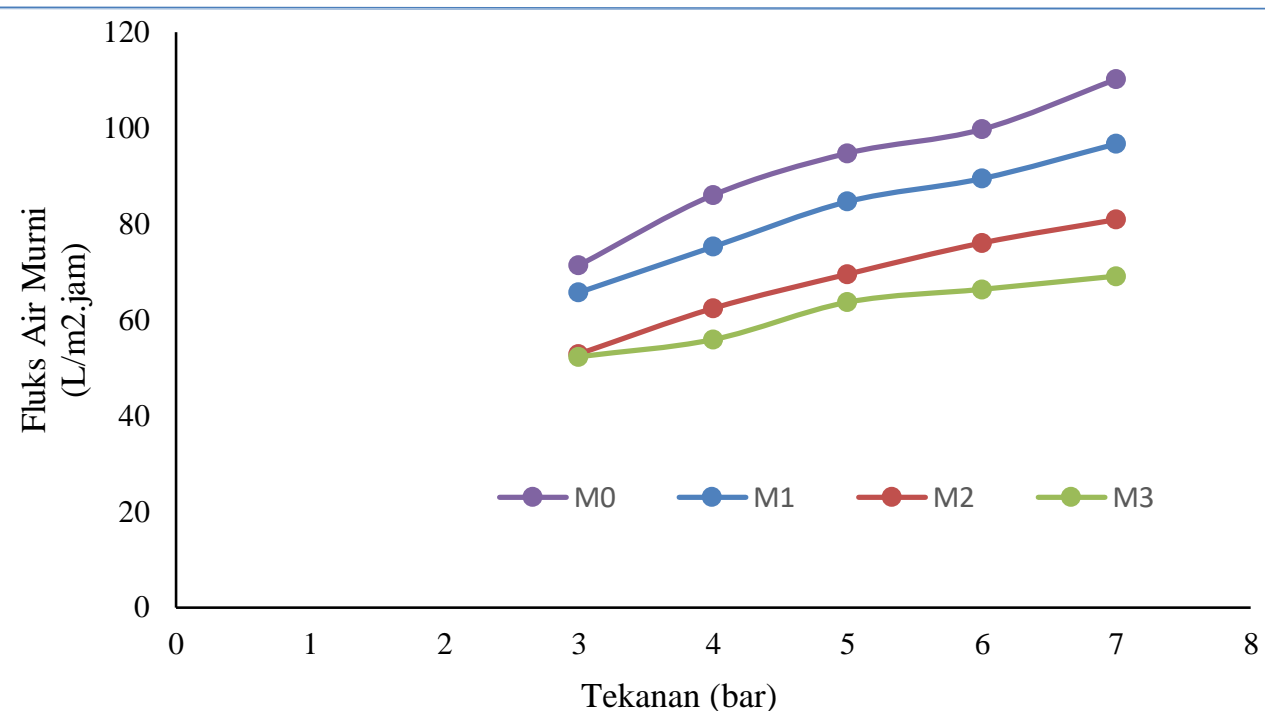

Gambar 1. Grafik hubungan nilai fluks air murni terhadap variasi tekanan pada berbagai jenis membran nanokitosan.

Sumber: Data penelitian (2020)

Berdasarkan Gambar 1 dapat kita lihat bahwa pada setiap membran yang sama, tekanan yang diberikan berbanding lurus dengan nilai fluks yang didapat, artinya semakin besar tekanan yang diberikan, maka nilai fluks yang dighasilkan juga akan semakin besar. Pada tekanan 7 bar, dihasilkan fluks air murni yang lebih besar untuk tiap waktu operasi dibandingkan dengan tekanan $3 ; 4 ; 5$; dan 6 bar. Pada membran M0 didapat nilai fluks air murni sebesar 71,40; 86,04; 94,76; 99,73; dan 110,18 L/m².jam. Pada membran M1 didapatkan nlai fluks sebesar 65,$72 ; 75,25 ; 84,66 ; 89,46$; dan 96,71 L/m².jam. Pada membran M2 didapatkan nlai fluks sebesar 52,$91 ; 62,42 ; 69,53 ; 76,04$; dan $80,92 \mathrm{~L} / \mathrm{m}^{2}$.jam. Sedangkan pada membran M3 didapatkan nlai fluks sebesar 52,32; 55,91; 63,69; 66,37; dan $69,13 \mathrm{~L} / \mathrm{m}^{2}$.jam untuk masing-masing tekanan 3; 4; 5; 6; dan 7 bar. Hal ini sesuai dengan daya dorong utama (driving force) pada aktivitas membran. Dengan bertambahnya tekanan pada aliran umpan yang melalui membran, menyebabkan ukuran pori-pori membran melebar sehingga fluks yang dihasilkan lebih besar [9].

Penambahan berat partikel nanokitosan ke dalam membran PES menghasilkan penurunan fluks pada setiap variasi tekanan untuk semua jenis membran. Dari data tersebut dapat disimpulkan bahwa konsentrasi nanokitosan pembentuk membran sangat mempengaruhi karakter membran yang terbentuk. Semakin tinggi konsentrasi partikel nanokitosan pembentuk membran maka membran yang dihasilkan akan semakin padat sehingga fluks air murni membran akan semakin kecil. Hasil permeabilitas keempat jenis membran diperlihatkan pada Tabel 2.

Tabel 2. Permeabelitas membran terhadap jenis membran

\begin{tabular}{ccc}
\hline Membran & $\begin{array}{c}\text { Pemeabilitas/Lp } \\
\left(\mathrm{L} / \mathrm{m}^{2} \text {.jam.bar }\right)\end{array}$ & Jenis Proses Membran \\
\hline M0 & 9,1237 & Nanofiltrasi \\
M1 & 7,618 & Nanofiltrasi \\
M2 & 6,9651 & Nanofiltrasi \\
M3 & 4,4077 & Nanofiltrasi \\
\hline
\end{tabular}

Sumber: Data penelitian (2020)

Membran M0, M1, M2 dan M3 menunjukkan nilai permeabilitas yang berbeda-beda, hal ini dikarenakan perbedaan struktur pada setiap membran. Komposisi larutan dope merupakan salah satu faktor yang mempengaruhi pembentukan struktur membran. Penambahan partikel nanokitosan sebagai aditif kedalam membran PES mempengaruhi nilai fluks dan permeabilitas membran. Membran M0 yang dibuat tanpa penambahan partikel nanokitosan memiliki nilai permeabilitas (Lp) yang paling tinggi, yaitu sebesar 9,1237 L/m².h.bar. Semakin besar konsentrasi partikel nanokitosan dalam membran PES menunjukkan nilai Lp yang semakin kecil. Berdasarkan nilai koefisien permeabilitas, membran M0, M1, M2 dan M3 tergolong membran nanofiltrasi, dimana membran M1, M2 dan M3 memiliki nilai Lp masing-masing sebesar 7,618; 6,9651; dan 4,4077 L/m².h.bar. Berdasarkan referensi, membran nanofiltrasi memiliki rentang fluks $1,4-12 \mathrm{~L} / \mathrm{m}^{2}$.h.bar pada rentang tekanan 5-20 bar [1]. 


\section{Swelling Degree dan Overall Porosity}

Untuk menentukan banyaknya zat atau bahan yang dapat diserap oleh membran, penting untuk dilakukan uji swelling. Data hasil pengukuran digunakan untuk menghitung nilai porositas dan derajat pengembangan membran atau swelling degree. Secara matematik porositas dan derajat pengembangan membran dapat diukur melalui persamaan 3 dan 4.

Kecenderungan nilai porositas membran komposit PES+Nanokitosan dapat dilihat pada Tabel 3. Porositas lapisan M0 memiliki nilai yang paling rendah yaitu $22,892 \%$. Hal ini terjadi karena membran yang dihasilkan kurang berpori [10]. Porositas meningkat dengan penambahan konsentrasi partikel nanokitosan. Nilai porositas membran M1, M2, dan M3 masing-masing adalah 32,360; 80,726; dan $117,016 \%$.

Kemampuan pengembangan membran dipengaruhi oleh nilai porositas. Besar kecilnya kapasitas penyimpanan air pada membran dipengaruhi oleh banyaknya rongga antar partikel (void space) atau porositas yang terbentuk [11]. Membran dapat menyerap air diakibatkan oleh beberapa faktor yaitu, pertama karena adanya gaya van der waals pada permukaan dan makro pori membran, yang kedua adalah munculnya ruang kosong yang terbentuk karena gelembung udara saat percetakan dimana saat terjadi pemanasan udara keluar meninggalkan ruang kosong antar partikel, dan yang terakhir adalah karena sifat alami dari bahan itu sendiri, yaitu kitosan.

\begin{tabular}{ccc} 
Tabel 3. Swelling degree dan overall porosity membran PES+Nanokitosan \\
\hline Membran & Overall Porosity $(\%)$ & Swelling Degree $(\%)$ \\
\hline M0 & 22,892 & 61,512 \\
M1 & 32,360 & 103,111 \\
M2 & 80,726 & 145,564 \\
M3 & 117,016 & 158,610 \\
\hline
\end{tabular}

Sumber: Data penelitian (2020)

Tabel 3 juga merepresentasikan nilai derajat pengembangan membran meningkat seiring dengan penambahan konsentrasi partikel nanokitosan. Peningkatan tajam persen derajat pengembangan membran pada konsentrasi nanokitosan 3\% terjadi dikarenakan persen intensitas gugus aktif kitosan yang dimiliki membran lebih besar, sehingga kemampuannya untuk mengikat air lebih besar. Ini dapat terjadi dikarenakan kitosan memiliki sifat higroskopis yaitu kemampuan untuk mengikat air [12]. Oleh sebab itu, derajat pengembangan membran juga dapat dipengaruhi oleh sifat alami dari kitosan itu sendiri.

\section{Stuktur Morfologi Membran Menggunakan SEM}

Pada penelitian ini dihasilkan membran asimetrik dari polimer dengan metode inversi fasa yang ditunjukkan dari hasil analisa SEM. Dapat dilihat pada Gambar 2 terdapat tiga lapisan yaitu lapisan dense, intermediet, dan penyangga. Lapisan dense yaitu lapisan selektif yang berada pada permukaan atas membran. Lapisan intermediet yaitu lapisan yang berada di antara lapisan dense dengan lapisan penyangga. Dan yang terakhir lapisan penyangga yaitu lapisan yang berfungsi sebagai penyangga mekanik membran. Pada penelitian ini dilakukan analisa morfologi pada membran PES tanpa penambahan kitosan (M0) dan membran PES dengan penambahan kitosan (M1, M2 dan M3).

Salah satu cara yang dapat digunakan untuk menentukan struktur morfologi membran (struktur permukaan dan penampang melintang) adalah dengan uji SEM [1]. Hasil analisa dari uji SEM berupa bentuk perubahan atau morfologi permukaan dari sampel yang dianalisis. Kecenderungan terjadinya perubahan energi, terjadi ketika ada perubahan pada suatu material seperti perubahan struktur permukaan. Perubahan energi ini dapat dipancarkan, dipantulkan, dan diserap serta diubah menjadi fungsi gelombang elektron yang dapat ditangkap dan dibaca hasilnya [13].

Dalam penelitian ini, dihasilkan membran asimetrik yang ditunjukkan dari hasil analisa SEM. Dapat dilihat pada Gambar 2 terdapat 3 lapisan yaitu lapisan dense, intermediet, dan penyangga. Lapisan dense adalah lapisan selektif yang berada di permukaan membran bagian atas. Lapisan intermediet adalah lapisan yang berada diantara lapisan dense dan lapisan penyangga. Terakhir, lapisan penyangga adalah lapisan yang berfungsi sebagai bantalan mekanis pada membran. Dalam penelitian ini, dilakukan analisa morfologi pada membran PES tanpa penambahan kitosan (M0) dan membran PES dengan penambahan kitosan (M1, M2 dan M3). Hasil analisa SEM struktur penampang melintang membran PES ditunjukkan pada Gambar 2 dengan perbesaran 500 kali. 


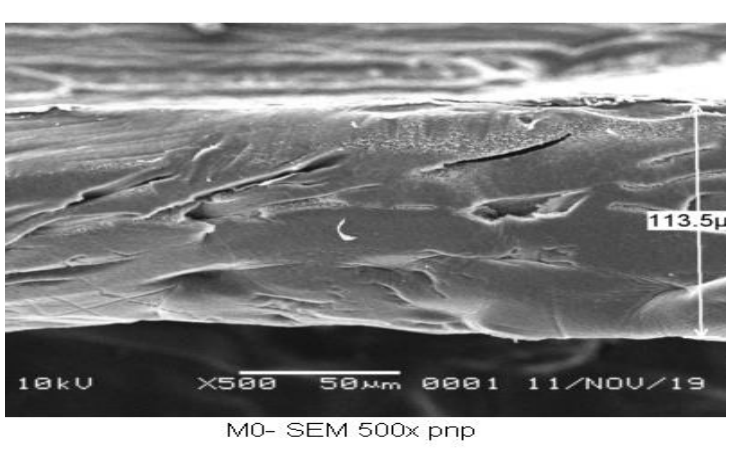

(a) M0

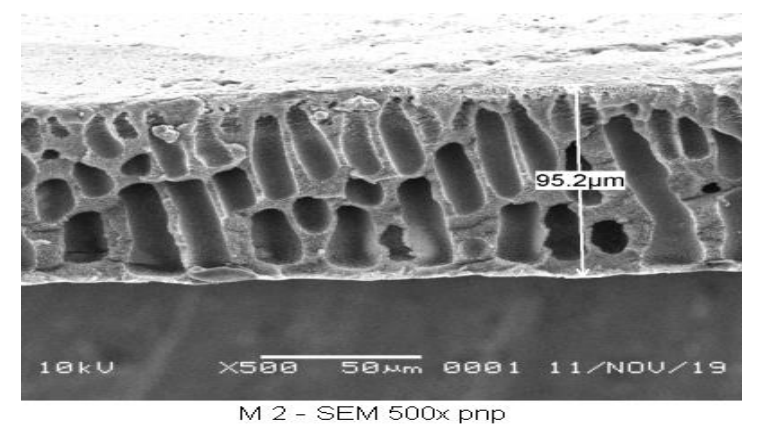

(c) M2

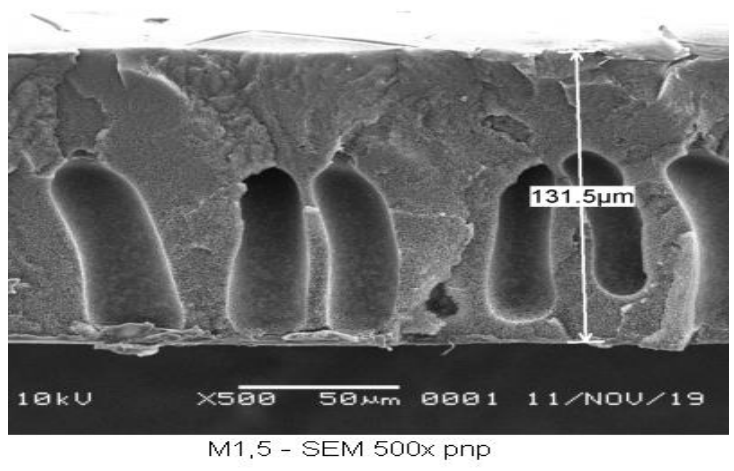

(b) M1

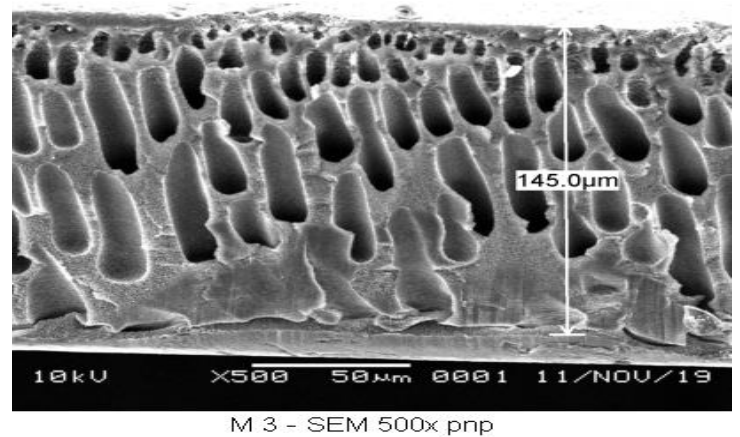

(d) M3

Gambar 2. Struktur penampang melintang membran (a) M0, (b) M1, (c) M2 dan (d) M3. Sumber: Data penelitian (2020)

Gambar 2 menunjukkan bahwa membran mermiliki struktur asimetrik dimana struktur pori bagian atas lebih rapat dibandingkan dengan struktur pori dibagian bawah. Perbedaan struktur morfologi membran M0 dengan membran M1, M2, dan M3 dapat dengan jelas terlihat pada Gambar 2. Dari beberapa gambar struktur penampang melintang di atas terlihat adanya rongga berbentuk seperti jari (finger-like macrovoid) pada membran. Finger-like macrovoid umum terjadi pada membran asimetrik, fenomena ini terjadi karena cairan dengan viskositas yang tinggi pada membran terdifusi oleh cairan dengan viskositas yang lebih rendah sehingga menyebabkan terbentuk rongga berbentuk jari atau biasa disebut finger-like macrovoid [14]. Jumlah dan panjang struktur macrovoid meningkat seiring dengan bertambahnya partikel nanokitosan pada membran PES. Struktur berbentuk spons pada bagian tengah membran juga mengecil seiring dengan penambahan aditif ini. Peningkatan ukuran pori tersebut diakibatkan karena sebagian aditif keluar dari membran pada saat proses koagulasi berlangsung [15].

Hasil SEM permukaan membran PES ditunjukkan pada Gambar 3 dengan perbesaran 20000 kali.

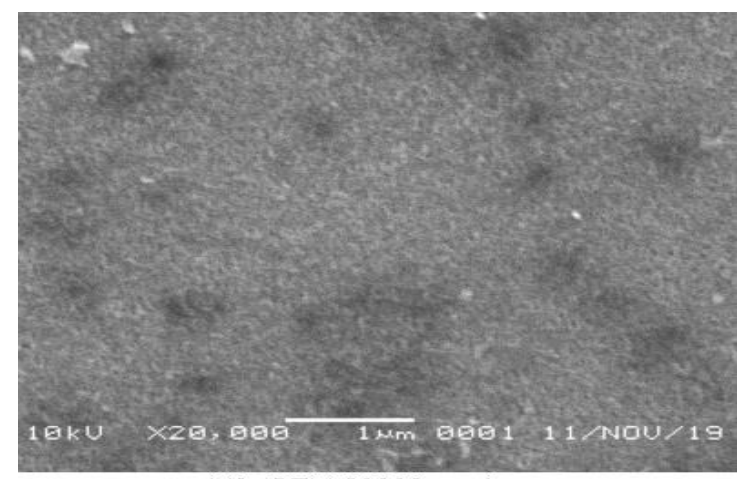

MO- SEM 20000x muka

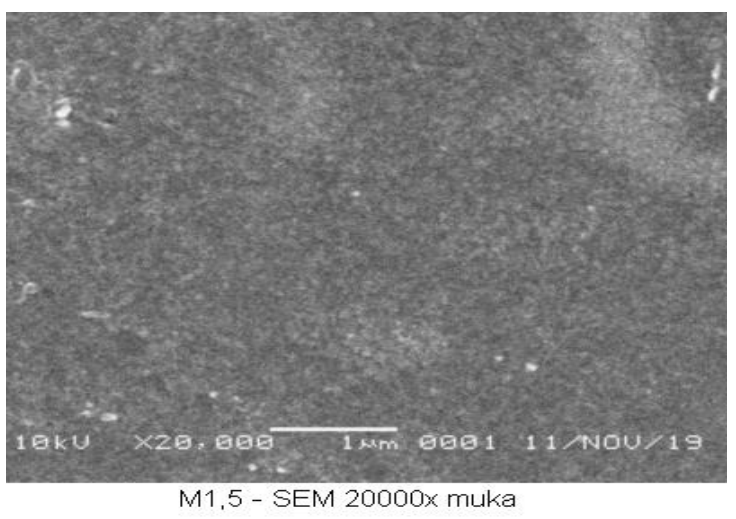

(b) M1 


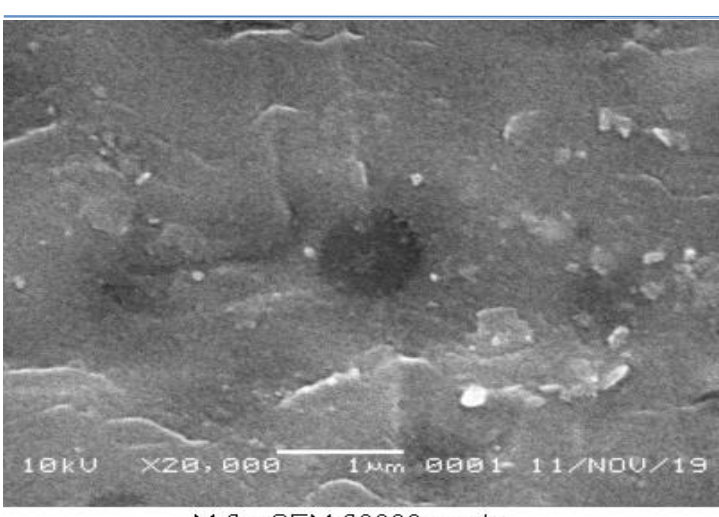

M 2 - SEM 20000x muka

(c) M2

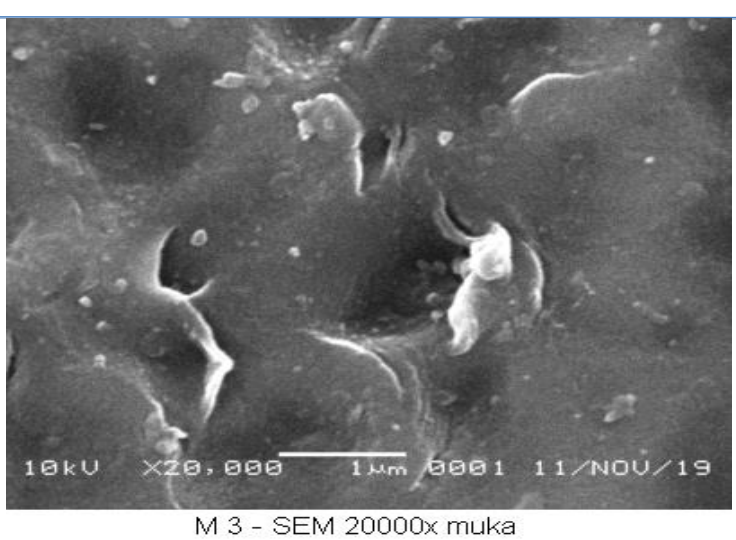

(d) M3

Gambar 3. Struktur permukaan membran (a) M0, (b) M1, (c) M2 dan (d) M3.

Sumber: Data penelitian (2020)

Dari Gambar 3 terlihat distribusi pori dari keempat jenis membran tersebut. Permukaan membran M2 dan M3 terlihat tidak rata. Hal ini diakibatkan karena proses percetakan membran dilakukan secara manual, sehingga membran yang dihasilkan memiliki ketebalan permukaan yang tidak sama. Dari Gambar 3 juga dapat terlihat pada membran terdapat void atau lubang kosong, hal ini terjadi dikarenakan polimer PES belum larut sempurna pada saat pembuatan larutan dope berlangsung [16].

\section{Gugus Fungsi Membran Menggunakan FTIR}

Karakterisasi Fourier Transform Infra Red (FTIR) yang dilakukan bertujuan untuk menentukan gugus fungsi atau komponen yang terdapat pada variasi membran tanpa penambahan partikel nanokitosan (M0) dan membran dengan penambahan partikel nanokitosan 1,5\% (M1), 2\% (M2) dan 3\% (M3). Berikut hasil analisa FTIR membran komposit PES+Nanokitosan dapat dilihat pada Gambar 4.

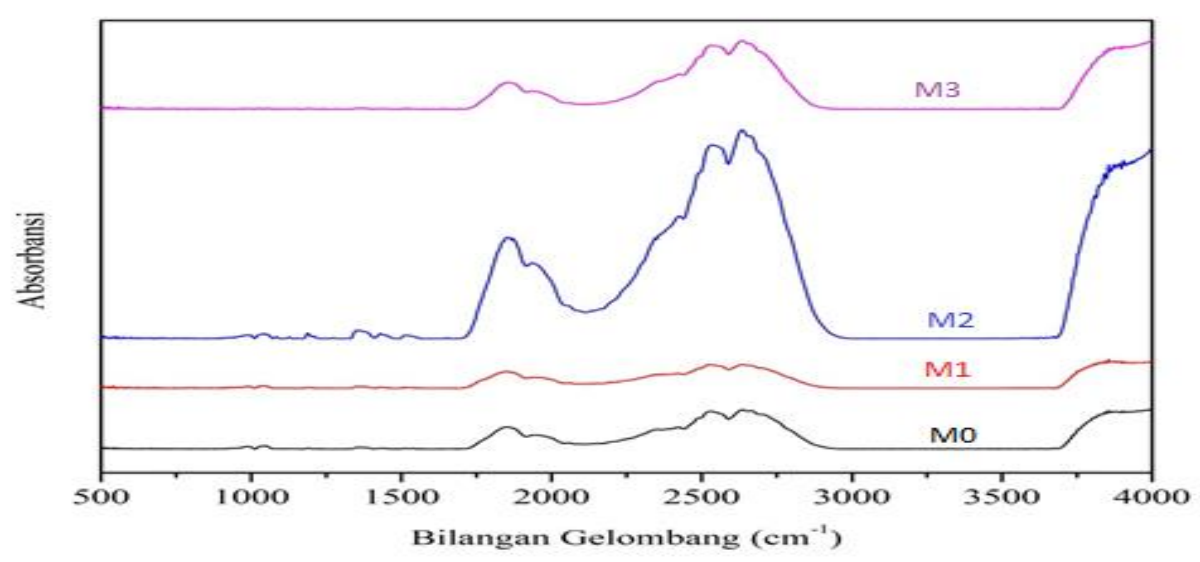

Gambar 4. Hasil analisa FTIR membran M0, M1, M2 dan M3

Sumber: Data penelitian (2020)

Tabel spektrum FTIR membran dengan variasi nanokitosan dapat dilihat pada Tabel 4.

Tabel 4. Spektrum FTIR membran M0, M1, M2, dan M3.

\begin{tabular}{cccccc}
\hline Gugus & Rentang Bilangan & \multicolumn{4}{c}{ Bilangan Gelombang $\left(\mathrm{cm}^{-1}\right)$} \\
\cline { 3 - 6 } Fungsi & Gelombang $\left(\mathrm{cm}^{-1}\right)$ & M0 & M1 & M2 & M3 \\
\hline C-C & $1510-1450$ & 1471,69 & 1492,90 & 1487,12 & 1494,83 \\
S-O & $1200-1100$ & 1205,51 & 1147,65 & 1170,79 & 1112,93 \\
C-O & $1270-1230$ & 1266,16 & 1232,51 & 1236,73 & 1237,08 \\
C-H & $900-670$ & 869,90 & 889,18 & 894,97 & 896,90 \\
O-H & $2700-2500$ & 2692,63 & 2590,40 & 2655,98 & 2657,91 \\
N-H & $3750-3000$ & - & 3564,45 & 3680,18 & 3682,11 \\
\hline
\end{tabular}

Sumber: Data penelitian (2020)

Secara umum, Tabel 4 menunjukkan hasil analisa membran PES tanpa modifikasi (M0) dan membran PES yang dimodifikasi dengan kitosan (M1, M2, M3) memiliki struktur spectrum yang hampir 
sama. Terlihat pada membran M0 terdapat kelompok gugus cincin aromatik (C-C) yang muncul pada bilangan gelombang 1471,69, kelompok gugus sulfon (S-O) pada bilangan gelombang 1205,51, kelompok gugus eter aromatik (C-O) pada bilangan gelombang 1266,16, kelompok gugus aromatik (C-H) pada bilangan gelombang 869,90 . Semua puncak bilangan gelombang yang muncul berkaitan dengan getaran atom yang berasal dari material yang mencirikan adanya PES. Terlihat pada membran M0 terdapat adanya peregangan getaran dari gugus hidroksil $(\mathrm{O}-\mathrm{H})$. Perlu diketahui bahwa polimer PES tidak memiliki ikatan O-H dalam strukturnya, peak yang muncul pada bilangan gelombang 2692,63 menunjukkan adanya peregangan $\mathrm{O}-\mathrm{H}$ dari molekul air yang disebabkan karena material berpori dapat menahan molekul air yang berasal dari bak koagulasi pada saat proses percetakan membran berlangsung [17].

Selain itu dari Tabel 4 dapat diketahui bahwa pada membran M1, M2 dan M3 terdapat kelompok gugus fungsi hidroksil (O-H) yang terdapat pada panjang gelombang 2590,40: 2655,98: 2657,91 dan kelompok gugus fungdi amina (N-H) yang terdapat pada panjang gelombang 3564,45: 3680,18: 3682,11. Hal ini menunjukkan adanya keberadaan rantai kitosan dalam material membran.

\section{Kesimpulan}

Penambahan konsentrasi partikel nanokitosan mempengaruhi karakteristik pada membran yang mana nilai LP semakin kecil dengan penambahan konsentrasi nanokitosan $0 ; 1,5 ; 2$; dan $3 \%$ yaitu 9,1237; 7,$618 ; 6,9651 ;$ dan $4,4077 \mathrm{~L} / \mathrm{m}^{2}$.h.bar. Sedangkan swelling degree dan overall porosity membran meningkat seiring dengan penambahan konsentrasi partikel nanokitosan yaitu 61,$512 ; 103,111 ; 145,564$ dan 158,610 $\%$ dan 22,$892 ; 32,360 ; 80,726$; dan $117,016 \%$. Penambahan partikel nanokitosan juga menyebabkan jumlah dan panjang struktur macrovoid meningkat serta struktur berbentuk sponge pada bagian tengah dari membran menjadi mengecil. Penambahan partikel nanokitosan juga penyebabkan lapisan atas menjadi tebal sehinga mempengaruhi nilai fluks dan rejeksi membran. keberadaan rantai nanokitosan bisa di lihat dari analisa FTIR yang mana pada membran M1, M2 dan M3 terdapat kelompok gugus fungsi hidroksil (O-H) yang terdapat pada panjang gelombang 2590,40: 2655,98: 2657,91 dan kelompok gugus fungsi amina (NH) yang terdapat pada panjang gelombang 3564,45: 3680,18: 3682,11.

\section{Referensi}

[1] Kurniawan, I., dan Mariadi, P.D. (2016). Review : Profil Hybrid Membrane Dalam Proses Reduksi Air Limbah. Konversi. 5(1): 1-10.

[2] Husni, D.A.P., Rahim, E.A dan Ruslan. (2018). Pembuatan Membran Selulosa Asetat Dari Selulosa Pelepah Pohon Pisang. Kovalen, 4(1): 41-52.

[3] Aryanti, P.T.P., Joscarita, S.R., Wardani, A.K., Subagjo., Ariono, D., dan Wenten, I.G. (2016). The Influence of PEG400 and Acetone on Polysulfone Membrane Morphology and Fouling Behaviour. J. Eng. Technol. Sci., 48(2): 135-149.

[4] Zahar, M.I.IM., Othma, M.H.D., Rahman, M.A., Jaafar, J., dan Hubadillah, S.K. A (2016). Morphological Study Of Nickel Oxide Hollow Fiber Membranes: Effect Of Air Gap \& Sintering Temperature. Jurnal Teknologi (Sciences \& Engineering) 78:12 75-81

[5] Ghaemi, N., Daraei, P., dan Akhlaghi, F. S. (2018). Polyethersulfone Nanofiltration Membrane Embedded by Chitosan Nanoparticles: Fabrication, Characterization dan Performance in Nitrate Removal from Water. Carbohydrate Polymers, Vol. 191, 142-151.

[6] M. Gagliardi. (2014). Global Market Sand Technologies for Nanofiltration. BCC Research.

[7] Hoshyargar, V., Fadaei, F., and Ashrafizadeh, S.N. (2015). Mass transfer simulation of nanofiltration membranes for electrolyte solutions through generalized Maxwell-Stefan approach. Korean J. Chem. Eng., DOI: 10.1007/s11814-014-0329-3

[8] Mulyati, S., Razi, F., dan Zuhra. (2017). Karakteristik Membran Asimetris Polietersufone (Pes) Dengan Pelarut Dimetil Formamide Dan N-Metil-2-Pyrolidone. Biopropal Industri. 8(1): 55-62.

[9] Kusumawati, N., dan Tania, S. (2012). Pembuatan dan Uji Kemampuan Membran Kitosan Sebagai Membran Ultrafiltrasi untuk Pemisahan Zat Warna Rhodamin B. Mipa Kimia Uns, 1, 43-52.

[10] Zulfi, F., Dahlan, K., dan Sugita, P. (2012). Adsorption of Waste Cr(VI) with Composite Membranes (Chitosan Silica Rice Husks). Makara J. Science, 16 (3), 163-168.

[11] Akbar, M. A. (2010). Pembuatan Membran Mikrofilter Zeolit Alam dengan Penambahan Semen Portland Putih. Universitas Islam Negeri Syarif Hidayatullah. Jakarta.

[12] Tanheitafino, S., Zaharah, T.A., dan Destiarti, L. (2016). Modifikasi Kitosan dengan Kaolin dan Aplikasinya Sebagai Adsorben Timbal (II). Jurnal Kimia Khatulistiwa, 5(2), 33-42.

[13] Mumpuni. (2011). Pembuatan Membran Komposit Pervaporasi Berbasis Poliether Sulfone Biopolimer untuk Dehidrasi Bioethanol. Thesis Teknik Kimia. Universitas Diponegoro. Semarang. 
[14] Ren, J., dan Wang, R. (2011). Preparation of Polymeric Membranes: Handbook of Environmental Engineering. Membrane and Desalination Technology. Vol. 13, 47-100.

[15] Arahman, N., Erika, C., dan Putra, A. (2013). Pemurnian Minyak Kelapa Sawit Menggunakan Membran Serat Berongga. Agritech, 33(1), 32-37.

[16] Muliawati, E.C. (2012). Pembuatan dan Karakterisasi Membran Nanofiltrasi untuk Pengolahan Air. Thesis Teknik Kimia. Universitas Diponegoro. Semarang.

[17] Ghiggi, F. F., Pollo, L. D., Cardozo, N. S. M. dan Tessaro, I. C. (2017). Preparation and Characterization of Polyethersulfone / N-Phthaloyl-Chitosan Ultrafiltration Membrane with Antifouling Propertty. European Polymer Journal, Elsevier, 92, 61-70. 